\title{
Social Media and Political Participation of Beginners
}

\author{
Lutfi Basit \\ lutfibasit@umsu.ac.id \\ University of Muhammadiyah Sumatera Utara, Indonesia
}

\begin{abstract}
Internet connected gadgets are being a lifestyle for millennial teens and often used to access politics. Its characteristics make it the most preferred media. Not a few politicians and political parties who use this media to build a political image to attract prospective voters, especially beginners in the context of social media relations and youth. Teenage users are also quite large, Technasia released that 26 million active social media users are 13-19 years old. This study aims to describe the interest of beginner voters in regarding the contents of political messages on social media and the potential political participation of novice voters in Medan. This research is descriptive and designed using a quantitative approach with purposive techniques in determining the sample. The number of samples is 40 students from several high schools in Medan. Respondents' answers were analyzed using a single table. The result of study show that novice voters have an interest in political content on social media, but are reluctant to bother responding to heavy levels, they just involved in a light way, this has become new in research. Although they were less interested in political information on social media, they stated that they would use their voting rights in the North Sumatra 2018 governor election. This proves that they have attention to politics, only reluctant to make heavy comments.
\end{abstract}

Keywords: Social Media, Political Participation, Beginner Voters

\section{Introduction}

The 2017 regional head elections in Jakarta between Basuki Tjahaja Purnama-Djarot and Anis Baswedan-Sandiaga Uno became the elections that drew the attention of not only the people of Jakarta but also the Indonesian people. There are several things that cause the election to draw attention, such as strong mass media support for the pair of one candidate pair and the existence of new space as a channel for political communication, that is social media.

The rivalry of the candidates for regional heads has a very significant impact on the dynamics of political communication in the public sphere. TV media which has been the referral communication channel for the community to follow the political process is disappointed because there are strong indications that TV media is not able to present the news in a balanced manner, which has an impact on the decline in the level of public trust such as the appearance of TV acronyms to TiVu (meaning cheats in Bahasa).

Besides TV, social media is also used as a place for contesting political communication messages. Social media is phenomenal in Indonesia's democratic party. Before social media becomes popular, personal opinions can become public opinion must be reported by the mass media. Now, with the characteristics of automatic distribution and its network, naturally popular conversations will be talked about in social media which makes one opinion spread 
quickly. So that social media becomes one of the word of mouth media or free publications and advertisements for campaign activities.

In a study conducted by Bismar Arianto on the Analysis of the Causes of People Not Choosing in Elections revealed an increase in the percentage of voters who did not exercise their right to vote, which was referred to as abstentions, individuals who did not exercise their right to vote. Since the era of reform, abstentional trends have tended to increase. The 1999 legislative election number reached 6.4\%, the 2004 legislative election increased to $15.9 \%$ and the 2009 legislative elections reached $29.1 \%$. The increase in abstentions does not only occur in the presidential election but also in the regional elections in some regions which reached 50\% as in the 2011 elections in Batam [1].

There are several factors that influence abstention behavior delivered by Tauchid Dwijayanto from the results of research conducted on the Abstentions Phenomenon in Central Java Governor Election 2008-2013, those are the lack of socialization, the community is more concerned with economic needs, and apathy towards the governor election.

In democratic political life voters have an important role to play in the ongoing political process and determine the winners of the political contest/celebration held. Hadar Nafis Gumay, Commissioner of the KPU said that the number of voters based on the Election Voters Potential Population Data (DP4) in 101 regions organizing 2017 Election was 41,802,538 consisting of 21,097,249 men and 20,705,289 women. Of these $2,236,672$ of them are beginner voters in February 2017. With such a large number, political communication in the context of political education for beginner voters must be carried out in a planned manner, including choosing communication media that can reach a large public and can be done with high intensity.

In the development of digital media today, social media has the ability to be an effective media that can reach the beginner voters. According to data released by Technasia active social media users amounted to 79 million a study with 26 million aged 13-19 years.

\section{Research Method}

This research is descriptive and designed with quantitative approaches with purposive techniques in determining the sample. To obtain the data and information needed, researchers also chose informants as resource persons who were considered able to provide information and data to support the success of this study. The respondents in this study were taken by high school students in Medan. These respondents were determined by purposive technique in accordance with the research objectives with the criteria are 17 years old at the North Sumatra Governor election in 2018 and Social media users.

Data is collected by obtaining data from books, papers, research journals, and other written materials related to research topics for secondary data. For primary data is carried out by Field Study, this field study was conducted by distributing questionnaires.

Quantitative data are analyzed using a single table. According to Singarimbun [2], single table analysis is the process of simplifying data into a form that is easier to read and interpret. So, the results of the questionnaire will be entered into a single table then read how many percentages are and then interpreted.

This study is intended to obtain an overview of the reality regarding the use of social media in political education and the interest of beginner voters in political communication on social media as well as the potential for political participation of novice voters 


\section{Result and Discussion}

\subsection{Social Media Concept}

The development of information and communication technology has changed the way individuals interact with other individuals. According to Solis and Breakenridge, social media is a democratization of content from the media and shifts the role of humans in reading and disseminating information including creating and sharing content. Social media is a shift from the broadcast mechanism model from many to many rooted in the format of the conversation between the writer and his colleagues in their social channels [3]. According to Yuswohady, this pattern has the power to sell a thousand and even a million times more powerful than the salesman chatter [4]. With the nature of communication many to many, the telling of a third person about a product/service/institution has a strong impetus to catapult someone/product/institution.

According to Tracy L. Tuten [5] social media refers to a participatory online community, there is conversation, and melting. This community allows members to produce, publish, control, criticize, improve, and interact with content that is online. To some extent, according to Tracy, all these community formats are social networks because all the interaction and maintenance features of the relationship are based on the number of participants. Now, one of the places where people gather is cyberspace. In cyberspace, social networks have evolved, some people spend time comforting with a social media application to capture motives and develop an online relationship. Varinder Taprial and Priya Kanwar [6] said that social media is a medium that allows a person to socialize or interact online by sharing content, news, photos and others with others.

According to Kandell, students are a group that looks more vulnerable to dependence on the internet than other community groups. Because students are in the emerging adulthood phase, namely the transition from late adolescence to young adults and experiencing psychological dynamics [7]. In this phase, students are in the process of forming self-identity, trying to live independently by freeing themselves from the dominance or influence of parents. Looking for the meaning of life and emotionally intimate interpersonal relationships. Emerging adulthood also has a less stable character such as interpersonal relationships, management of life needs, emotional and cognitive development. When individuals experience difficulties in their development, then to overcome this the use of the internet becomes more important than what other people do in general, because online activities can expand and strengthen their social networks [8].

\subsection{Concept of Political Participation}

Political participation is the activity of a person or group of people to actively participate in political life, namely by choosing a state leader directly or indirectly influencing government policy. Helbert McClosky in international encyclopedia of the social sciences said that political participation is the voluntary activities of citizens through which they take part in the process of electing the authorities, and directly or indirectly, in the process of forming public policy. Samuel P. Huntington and Johan M. Nelson, No easy choice: political part recognition in developing countries say that political participation is an activity of citizens who act as individuals, which is intended to influence decision making by the government. 


\subsection{Concept of Beginner Voters}

According to Article 1 paragraph (22) of Law No. 10 of 2008, voters are Indonesians who have reached the age of 17 (seventeen) years or more or have been married/ever married, then Article 19 paragraphs (1 and 2) Law No. 10 In 2008 explained that voters who have the right to vote are Indonesian citizens who are registered by the election organizer in the voter list and on polling day are even 17 (seventeen) years or older or have been married.

According to Law No. (32) of 2004 from Article 56 to Article 119 of the election of Regional Heads and Deputy Regional Heads, the direct election stage includes the stages of Registration and Determination of Candidates, Campaigns, Determination of Voters List, Calculation of Voters, Determination of Elected Candidate Pairs, Validation and Inauguration, and cost stage Monitoring and implementation of election.

\subsection{Political Communication}

In political communication, there are two major concepts, there are the concept of communication and political concepts. Communication is defined as the process of delivering information between the sender to the recipient through a particular medium. An expert, Theodore M. Newcomb, explained that communication is every action that is seen as a process of transmitting information which consists of a discriminatory stimulus from the source of information to the recipient of the information.

Furthermore, Harold Lasswell in Cangara's book defines the concept of political science as a science related to power. According to Dahlan, political communication is interpreted as a discipline that examines communication behavior and activities that are politically charged, have political consequences or have an influence on political behavior and activities. This political communication can be defined as a process of communication that has consequences for political actions.

Political Communication serves to convey information to the public about what is happening and developing around the community. Political communication media serves as a means of observation and monitoring to find out the condition of the surrounding community and provide political education to the community about the meaning and meaning of the facts that occur in the community itself. Political communication media also has the obligation to look at facts objectively so that they can present them to the public objectively. Media of political communication can be a means to accommodate political problems that develop in the community. With the existence of political communication media, political issues can be discussed clearly and the media can shape public opinion. Political communication media is also obliged to convey the results of public opinion to the community itself and become a means of publication for the government of the country and institutions of a political nature as well as a means of advocacy for political policy.

\subsection{Utilization of Social Media}

Most respondents know (67.5\%) about political content on social media. While $32.5 \%$ others do not know the political content that is on social media. Respondents expressed various opinions related to social media that were used as media to convey political activities and messages. As many as $82.5 \%$ agreed that social media was used as political media, while $15 \%$ disagreed and only 1 person $(2.5 \%)$ did not know. In the table shows that TV media is still the main source for respondents to get political information (45\%). Sources from social media only in the second rank position (40\%). While respondents who received political information from newspapers were only $10 \%$ and radio 5\%. Although the source of information to get political information is TV, but respondents who are interested in getting information about politics through social and social media still dominate the respondents' answers, as much as $60 \%$, and those who are not interested by $40 \%$.

\subsection{Beginner Voter Interest}

The duration of time commonly used to access social media is less than 1 hour $(62 \%)$ and $22.5 \%$ use $1-3$ hours then the rest use more than 3 hours. While the frequency used to access 
social media a day is mostly $1-10$ times (80\%), $7.5 \%$ access social media 11-20 times and $12.5 \%$ more than 20 times.

When compared to other social media, whatsapp is the most accessed social media (47\%), followed by facebook, twitter and line. Respondents use mobile devices to access social media more than desktop computers.

There are many reasons for accessing social media related to politics. Some of the respondents $(60 \%)$ access social media to fill the vacancy, $32.5 \%$ because they were interested in politics, while 3 people $(7.5 \%)$ accessed social media because of interesting in politicians. Even so, $57.5 \%$ of respondents did not create an account to be able to access information about politics in social media, and only $42.5 \%$ who created an account. Respondents who deliberately access political information on social media only 9 people $(22.5 \%)$ and 31 people $(77.5 \%)$ access it accidentally. They read information related to politics 1-5 times a day.

\subsection{Political Participation}

One of the most interesting things for respondents is reading political party profiles on social media (80\%), while the rest have never read it. however, only 12.5 percent responded via hashtags and just 22.5 percent become a follower. They were not active in giving opinions or responding to status or political information in the comments column of a news/information about politics (67\%), they just give a sign of likes/dislikes to a news/information about politics in social media (60\%). Even so, they (90\%) sure to use their voting rights in the 2018 governor election.

\subsection{Discussion}

The data above shows that beginner voters $(67.5 \%)$ are aware of political content on social media. They do not argue that social media is used as a medium for political activities and conveying political messages. Social media is indeed one of the means of information that is widely used by people today. Therefore political parties and politicians and individuals or groups that have political interests utilize social media that has four benefits for political activity, those are Information, service, access to political power and space. Douglas Hagar (2014) in Campaigning Online: the Social Media in the 2010 Niagara Municipal Elections said, social media can contribute to political success because social media makes candidates in an election able to interact with potential voters with a scale and intensity that cannot be achieved through traditional campaigns patterns such as door-to-door campaigns, brochures, and even coverage by print and television media. However, in this study shows that TV media is still a favorite as a source that is used to get information related to politics and put social media as a second choice. Although novice voters place social media as the second source to get political information, but their interests are quite large in political information $(60 \%)$. This still provides an opportunity for political communicators to create more interesting political messages on social media.

The nature of political communication between candidates and prospective voters can be multi-directional, such as from candidates to voters, voters to candidates, or between voters. This multi-directional communication capital, according to Tasente Tanase (2015) in The Electoral Campaign through Social Media: A Case Study-2014 Presidential Election in Romania, becomes one of the capital for candidates to win votes in the election. Tasente argued, the opportunity for social media support to be a voice in the election is greater if there is active involvement or participation of prospective voters. Political participation of beginner voters in the mass media is shown by being a follower, giving comments, just expressing their opinions by giving emoticons, writing support words, or making support tags in political party accounts or politicians or sympathizers of political parties. In this study shows that the political participation of the beginner voters is still relatively small between $5 \%-42 \%$.

With the conditions of the media use above, then in the context of social media users as political sources, voters can be categorized as passive users in social media. Askalani [9] explains that social media users can be distinguished based on how active or passive the user is in using social media. Active or passive use is distinguished based on how users use various functions in social media, such as seeing images, various thoughts or experiences, clicking on certain links or symbols as a form of feedback, or just browsing the content of social media pages. Active users are social media users who engage in online interactions with other users through various social media features such as commenting on other users' 
posts, posting status or photos, or using the chat feature. Users actively control the dialogue and freely share personal information. Users who are active will carry out these activities. In contrast, passive users are social media users who are less involved in interactions using online features. Passive users will only browse the contents of social media pages without being actively involved in online interactions through various social media features, including clicking on certain links or symbols, receiving and commenting, posting status, photos, or links, or using the chat feature.

The average beginner voters use around 1 hour a day to access social media with frequency of use 1-10 times. Indeed, there are novice voters who access social media more than 20 times but only $12.5 \%$. Mobile phones are the main device used to open social media compared to desktop computers and other devices. Of the several types of social media, WhatsApp is the most commonly used application (47\%) even compared to Facebook.

In connection with the reason that the beginner voters access social media related to politics, it turns out that the majority is only to fill the void, only a small percentage are really interested in politics or the figure of a politician. This was strengthened by the results of the answer that as many as $57.5 \%$ of novice voters did not create a special account to be able to access information about politics and the majority did not intentionally open information/issues around politics on social media $(77.5 \%)$. The frequency of beginner voters reading information/political issues on social media ranges from 1-5 times a day $(62.5 \%)$.

This is in line with the research conducted by Latifah Kadir about the motives of teenagers for the use of Facebook networking sites at students of SMK Negeri 7 Samarinda. There are several motives that are the reason they use social media, namely information motives, personal identity motives, integration motives and social interactions and entertainment motives. When compared between the four motives, the motive for integration and social interaction that is more influential in adolescents (students) is $86 \%$. The entertainment motive is $84 \%$, while the motive for seeking information is very small [10].

Likewise, the research conducted by Juwono related to the dynamics of youth political participation through social media, shows the same thing. Respondents' attention and participation were low in political matters, only 26 respondents out of 95 respondents, although all respondents said they had received a message about politics. Form of participation by giving comments, candidate followers, giving opinions, and political party followers [11]. But when asked about the possibility of exercising the right to vote in the North Sumatra Governor election in 2018, most of the new voters will use their voting rights.

\section{Conclusion}

Beginner voters have an interest in political content on social media, but lack of political participation through social media even in this context tends to be passive users who are reluctant to bother responding to heavy levels such as writing statements of support, responses, comments, or making hashtags. They only convey their involvement by responding in a light way on social media such as giving emoticons.

Beginners have great potential to exercise their right to vote, although the duration and frequency of accessing social media with political content is lacking, but they also take the time to read good profiles of political party profiles and become followers, so they feel confident they will participate in the political process by using their suffrage in the North Sumatra 2018 governor election.

\section{References}

[1] Arianto, Bismar: Analisis Masyarakat Tidak Memilih dalam Pemilu. Jurnal Ilmu Politik dan Ilmu Pemerintahan. Vol. 1, No. 1, pp. 51-52. (2011)

[2] Singarimbun, Masri: Metode Penelitian Survey. LP3ES, Jakarta (2002)

[3] Solis, Brian dan Breakenridge, Deirdre: Putting the Public Back in Public Relations. FT Pers, New Jersey, pp. xvii (2009)

[4] Yuswohady: Crowd, Marketing Becomes Horizontal. , Gramedia Pustaka Utama, Jakarta, pp.5 (2008) 
[5] Tuten, Tracy L: Advertising 2.0, Social Media Marketing In A Web 2.0 World. Preager Publisher, Westport, pp. 20 (2008)

[6] Taprial, Varinder dan Kanwar, Priya: Understanding Social Media. Ventus Publishing Aps., pp. 8 (2012)

[7] Kandell, J. J.: Internet Addiction On Campus: The Vulnerability Of College Students, Cyberpsychology \& Behavior. Vol. 1, No 1, pp. 5 (1998)

[8] Smahel, D., Brown, B. B., \& Blinka, L.: Associations between Online Friendship and Internet Addiction among Adolescents and Emerging Adults, Jurnal Developmental Psychology 48 (2), pp. 2 (2012) 
[9] Askalani, M.L: Staring at the sun: Identifying, understanding, and influencing social media users (2012). Downloaded from http://aimmia.com/files/doc_downloads/Aimia_SocialMedia_ Whitepaper.pdf (accessed on 13 July 2018)

[10] Kadir, Latifa: Motif Remaja Terhadap Penggunaan Situs Jejaring Facebook (Siswa Smk Negeri 7

[11] Samarinda). eJournal Ilmu Komunikasi. 2014, 2 (4): 53-63, ejournal.ilkom.fisip-unmul.ac.di, pp. 53 (2014)

[12] Atmodjo, Juwono Tri: Dinamika Partisipasi Politik Remaja Melalui Media Sosial. Jurnal Visi Komunikasi Vol 13, No. 02, November 2014: 281 - 295 (2014) 